\title{
抗炎症剤，ナブメントのラット尿中代謝物の単離と同定
}

\author{
石橋 光治, 石村 里佳, 土屋 為弘, 野口 英世 \\ 藤沢薬品工業秼・開発研究所 $\overline{7} 532$ 大阪市淀川区加島 2 丁目 1 番 6 号 \\ 島谷 憲司, 佐藤 明啓 \\ 藤沢薬品工業秼・物性研究所 $\overline{\mathrm{T}} 532$ 大阪市淀川区加島 2 丁目 1 番 6 号
}

Key words : Nabumetone/4-(6-Methoxy-2-naphthyl)butan-2-one/Anti-inflammatory drug/Urinary metabolites/Identification/Rats

\section{Isolation and identification of urinary metabolites of nabumetone in rats}

Koji Ishibashi, Rika Ishimura, Tamehiro Tsuchiya and Hideyo Noguchi

Product Development Laboratories, Fujisawa Pharmaceutical Co., Ltd.,

1-6, 2-Chome, Kashima, Yodogawa-ku, Osaka 532

Kenji Shimatani and Akihiro Sato

Analytical Research Laboratories, Fujisawa Pharmaceutical Co., Ltd., 1-6, 2-Chome, Kashima, Yodogawa-ku, Osaka 532

\section{Summary}

The metabolites of nabumetone, a new nonsteroidal anti-inflammatory agent, were identified in rats. Urine from rats dosed orally with nabumetone was hydrolysed with a mixture of $\beta$-glucuronidase and arylsulfatase and extracted with ethyl acetate. Sixteen metabolites were isolated by HPLC and TLC from urine extracts and then structual analysis was carried out using IR, NMR and mass spectrometry. The results showed that nabumetone was metabolized by various reactions involving demethylation of the methoxy group, reduction of the ketone group, hydroxylation of the alkyl side chain and cleavage of the $\mathrm{C}-\mathrm{C}$ bond. A major urinary metabolite was 6-hydroxy-2-naphthylacetic acid (M-I), and minor metabolites were 2,3-dihydroxy-4-(6-hydroxy-2-naphthyl)butan-4-one (M-XII), 6-hydroxy-2-naphthoic acid (M-XIII) and 3-(6-hydroxy-2-naphthyl)propionic acid (M-XV), accounted for 32.4, $7.4,5.9$, and $2.9 \%$ of the administered dose, respectively, which were predominantly excreted as conjugates. Identified metabolites accounted for about $55 \%$ of the dose. 


\section{緒 言}

ナブメトン,4-(6-methoxy-2-naphthyl)butan2-one は, 英国ビーチャム社で合成された非酸性 の非ステロイド性抗炎症剤であり, ひろい抗炎症 活性スペクトルを有し, 酸性抗炎症剤に比べて胃 粘膜刺激などの副作用が少ないと考えられてい る1).

ナブメトンのヒトおよび実験動物に括ける体内 動態は, すでに Haddock らによって報告され ている.ナブメトンは体内で速やかに代謝され， そのほとんどが代謝物として尿中に排泄される。 ラットに ${ }^{14} \mathrm{C}$-ナブメトンを経口投与すると，投 与後 24 時間までの尿中に投与量の $87.6 \%$ が排泄さ れる.尿中には未変化体はほとんど認められず, 主 代謝物として 6-hydroxy-2-naphthylacetic acid と、ごくわずかの 6-methoxy-2-naphthylacetic acid 括よび 4-(6-hydroxy-2-naphthyl)butan-2one が同定されているが，去の他の代謝物につい ては明らかにされていない，今回，これら以外の 代謝物を単離・精製し,構造推定を行った。また， 尿中代謝物の排泄率も測定した。

\section{英験材料および方法}

\section{1. 標識化合物}

${ }^{14} \mathrm{C}$-ナブメトンの化学構造ならびに標識位置を

Fig. 1 に示した.

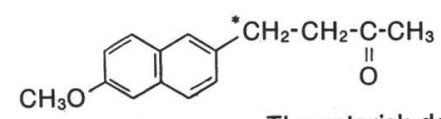

The asterisk denotes

the labelled position

Fig. 1. Chemical structure of ${ }^{14} \mathrm{C}$-nabumetone.

本実験に用いた標識化合物の比放射能 は 18.1 $\mu \mathrm{Ci} / \mathrm{mg}$ ，薄層クロマトグラフィー（TLC）によ り求めた放射化学的純度は $99 \%$ 以上であった。

\section{2. 合成標品}

ヒトならびに実験動物の尿中代謝物として，す でに構造が明らかとなっている代謝物の標品, 6-hydroxy-2-naphthylacetic acid(M-I), 6-methoxy-2-naphthylacetic acid (M-II), 4-(6-hydroxy-2-naphthyl) butan-2-ol(M-III), 4-(6-hydroxy-2-naphthyl)butan-2-one(M-IV) および 4-(6-methoxy-2-naphthyl)butan-2-ol (M-V) は, 英国ビーチャム社で合成されたものを用いた。

\section{3. 実験動物}

体重 210 250 g の Sprague-Dawley 系雄性 ラットを用いた。実験期間中，水・飼料は自由に 与帛た。

\section{4. 薬物投与および試料採取法}

4 匹のラットに ${ }^{14} \mathrm{C}$-ナブメトンを $1 \%$ ×チル セルロース懸濁液として $20 \mathrm{mg} / \mathrm{kg}$ 経口投与し, 代謝ヶージ中で 2 日間飼育した. その間, 䔬は室 温で, 尿は氷冷下で採取し, 代謝物の検索および 定量に用いた．また別に，20匹のラットに非標識 ナブメトンを $1 \%$ ×チルセルロース懸濁液として $300 \mathrm{mg} / \mathrm{kg} / \mathrm{day}$ ，17日間にわたり経口投与した. 最終投与後 24 時間まで室温で採尿し, 代謝物の単 離に用いた。

\section{5. 放射能の計測}

尿, 投与液のメタノール希釈液, 凍結乾燥した 尿のメタノール抽出液ならびに高速液体クロマト グラフィー（HPLC）に拈ける分取液は，その一 部をバイアルに取りアクアゾル (NEN) を加えて 計測した。

翼は水で10\%ホモジネートにした後, 一部をサ ンプリングし，プロトゾル（NEN）を加えて加 温, 溶解後 $1 \mathrm{~N}-\mathrm{HCl}$ : アクアゾル $(1: 9, \mathrm{v} / \mathrm{v})$ を加觉て測定した．代謝物をTLCで分離後，放 射活性部位のシリカゲルなど削り取り試料は, メ タノールを加えて放射能を溶出した後, トルェン シンチレーターを加光て計測した、放射能の計測 は液体シンチレーションカウンター (Packard Model 4640) で行い, 試料のクエンチング補正 は外部線源法によった.

\section{6. 薄層クロマトグラフィー}

シリカゲルプレート (Kieselgel $60 \mathrm{~F}_{254}, 20 \times$ $20 \mathrm{~cm}$, 厚さ $0.25 \mathrm{~mm}$, Merck) と RP-8 (RP-8 $\mathrm{F}_{254}, 20 \times 20 \mathrm{~cm}$, 厚さ $0.25 \mathrm{~mm}$, Merck) を用い た。展開溶媒系は

(1) クロロホルム：メタノール：氷酢酸

$(90: 30: 2, \mathrm{v} / \mathrm{v})$

(2) クロロホルム：メタノール：氷酢酸

$(90: 10: 2, \mathrm{v} / \mathrm{v})$

(3) クロロホルム：酢酸エチル：氷酢酸

$(90: 30: 2, \mathrm{v} / \mathrm{v})$ 
(4) クロロホルム：酢酸エチル：氷酢酸

$(90: 20: 2, \mathrm{v} / \mathrm{v})$

(5) クロロホルム: 氷酢酸 $(100: 2, \mathrm{v} / \mathrm{v})$

(6) 酢酸エチル：イソプロパノール：氷酢酸

$(90: 10: 2, \mathrm{v} / \mathrm{v})$

(7) 酢酸エチル：イソプロパノール:氷酢酸： 水

$(90: 10: 8: 2, \mathrm{v} / \mathrm{v})$

(8) 酢酸エチル：承酢酸

$(200: 1, \mathrm{v} / \mathrm{v})$

(9) 酢酸エチル：承酢酸

$(100: 2, \mathrm{v} / \mathrm{v})$

(10) ベンゼン: 酢酸エチル

$(7: 2, \mathrm{v} / \mathrm{v})$

(11) ヘキサン: 酢酸エチル

$(7: 2, \mathrm{v} / \mathrm{v})$

(12) アセトニトリル：1\%酢酸

$(6: 4, \mathrm{v} / \mathrm{v})$

(13) メタノール：5\%酢酸

$(6: 4, \mathrm{v} / \mathrm{v})$

(14) メタノール $5 \%$ 酶酸

$(10: 95, \mathrm{v} / \mathrm{v})$

(15) 酢酸エチル

を用いた。

スポットの検出は,短波長 UV ランプ $(254 \mathrm{~nm}$, マナスル工業) と長波長 UV ランプ（366 nm, UVP INC.）を照射することにより行った。また， ナフタレン環のメトキシ基が脱アルキルを受けた 代謝物が予想されたことから，フェノール試薬に よる呈色反応も試みた。

放射性代謝物の確認のため, TLC 展開後 SAKURA X-RAY FILM ${ }^{\text {NEW }}$ A,'medical あるい は SAKURA MACRO AUTORADIOGRAPH FILM, ${ }^{3} \mathrm{H}$ TYPE (いずれも小西六写真工業) を 用いてオートラジオグラムを作製した。

\section{7. 高速液体クロマトグラフィー}

高速液体クロマトグラフは Varian LC 5060 を 用いた。

尿中代謝物の分画ならびに精製の最終工程に特 ける HPLC 条件は, カラム: TSK-GEL ODS$120 \mathrm{~T}$ ( $5 \mu, \phi 7.8 \times 300 \mathrm{~mm}$, 東洋曹達), 移動相 :グラジェント法 (メタノール : $1 \%$ 酶酸 (3: 7 , $\mathrm{v} / \mathrm{v})$ を15分間で $(8: 2, \mathrm{v} / \mathrm{v})$ 飞变化させた $)$,

流速: $3 \mathrm{ml} / \mathrm{min}$, 検出法: UV $330 \mathrm{~nm}$ 物よび TRACE 7140 (Packard).

代謝物 M-VII, M-VIII の単離はカラム: NOVA-PAK $\mathrm{C}_{18}(5 \mu$, Waters), 移動相 : グラ ジェント法 (メタノール : $1 \%$ 酢酸 $(3: 7, \mathrm{v} / \mathrm{v})$ を15分間で $(8: 2, \mathrm{v} / \mathrm{v})$ に変化させた $)$, 流速 : $1.2 \mathrm{ml} / \mathrm{min}$, 検出法: UV $330 \mathrm{~nm}$. 代謝物 M-XIV の単離にはカラム : NOVA-PAK $\mathrm{C}_{18}$, 移動相 :
メタノール: 水 $(1: 1, \mathrm{v} / \mathrm{v})$, 流速 : $1.2 \mathrm{ml} / \mathrm{min}$, 検出法 : UV $330 \mathrm{~nm}$ 打よびカラム : LiChrosorb SI 60 , 移動相 : クロロホルム : 酢酸エチル $(9: 1$, $\mathrm{v} / \mathrm{v})$, 流速 : $1.0 \mathrm{ml} / \mathrm{min}$, 検出法 : UV $330 \mathrm{~nm}$ で行った.

\section{8. 代謝物の構造解析}

\section{8-1 核磁気共鳴スペクトル（NMR）}

${ }^{1} \mathrm{H}$ および ${ }^{13} \mathrm{C}-\mathrm{NMR}$ は測定溶媒として DMS $\mathrm{O}-\mathrm{d}_{6}$ (必要なら重水を添加)を用い, JNM-FX270 （日本電子）により測定した。なお，内部標準と してテトラメチルシラン（TMS）を用いた.

\section{8-2 質量スペクトル（MS）}

EI-MS は直接導入法により JMS-D 300質量分 析計（日本電子）あるいは Hitachi M-80 質量分 析計（日立製作所）で, SIMS は Hitachi M-80 質量分析計で測定した. 測定条件は EI-MS の場 合, イオン化ェネルギー：70 ev，イオン加速電圧 $: 3 \mathrm{KV}$, 試料加熱温度: $100 \sim 300^{\circ} \mathrm{C}$, SIMS の場 合は一次イオン種: $\mathrm{Xe}^{+}$, イオン加速電圧: $8 \mathrm{KV}$, マトリクス：グリセロールあるいはグリセロール +DMSO で行った.

\section{8-3 赤外線吸収スペクトル（IR）}

Nujol 法を用い，IR-420 型（島津製作所）で 測定した.

\section{8-4 元素分析}

単離・精製した代謝物のうち, 必要なものにつ いては YANAKO CHN CORDER MT-3（柳 本製作所）により測定した.

\section{9. 尿中代謝物の定量}

${ }^{14} \mathrm{C}$-ナブメトンを投与後のラットプール尿に 2 倍容の $\mathrm{pH} 5$ 酢酸緩衝液を加えた後, 1/10容量の $\beta$-glucuronidase/arylsulfatase(from Helix pomatia, それぞれ $5.2 \mathrm{U} / \mathrm{ml}, 2.6 \mathrm{U} / \mathrm{m} l$, Boehringer Mannheim $\mathrm{GmbH}$ ) を加光, $37^{\circ} \mathrm{C} て ゙ 24$ 時間イン キュベーションした. 酵素非水解尿ならびに上記 酵素水解尿を涷結乾燥後, 放射能をそれぞれメ夕 ノールで抽出した。この時, 抽出物の放射能を測 定し，いずれも注㜔全に抽出されていることを 確認した. 得られたメタノール抽出物を HPLC に注入し，すでに述べたグラジェント溶出条件下 放射能のクロマトグラムに従い，12個のフラクシ ョンに分画した (Fig. 2). 注入放射能量拉よび各 フラクションに含まれる放射能を測定し，カラム 


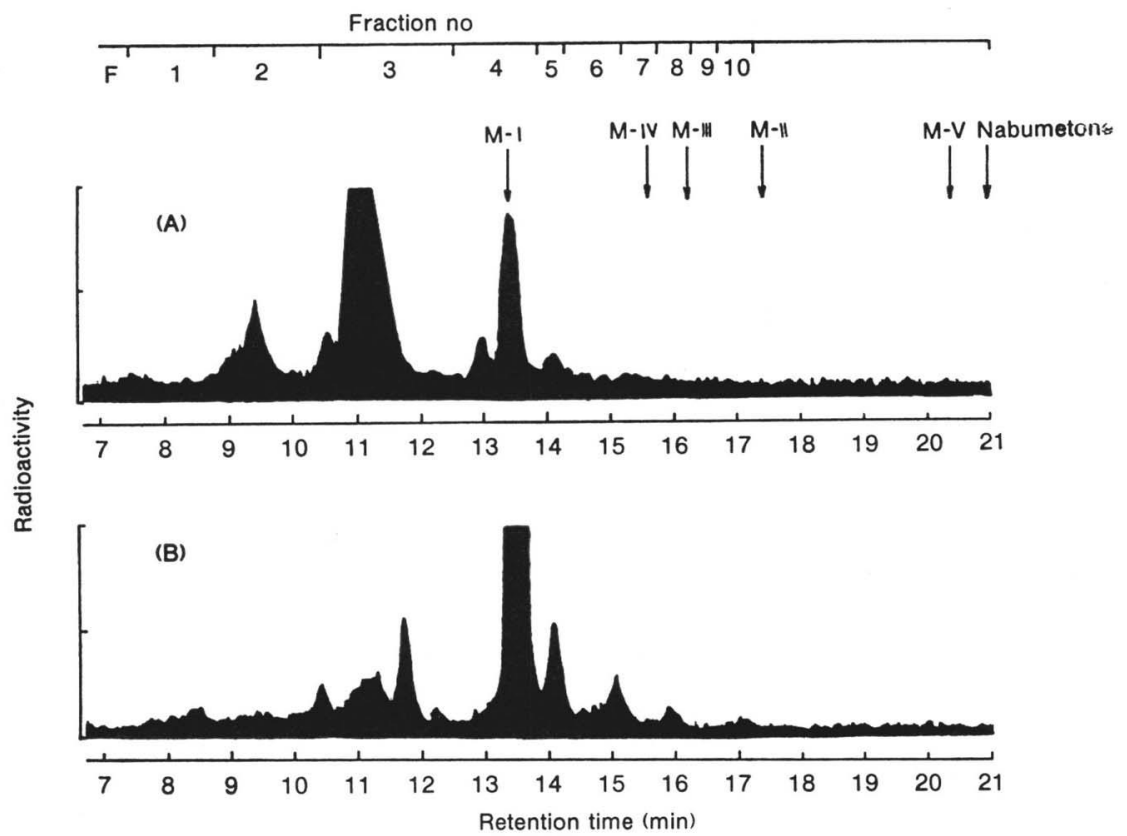

Fig. 2. Radiochromatograms showing HPLC separation of urinary metabolites after oral dosing of ${ }^{14} \mathrm{C}$-nabumetone at $20 \mathrm{mg} / \mathrm{kg}$ to rats.

(A) before hydrolysis, (B) after hydrolysis.

への吸着がないのを確認の上, 放射能の分布を求 めた. 次に, 分取した各フラクションについて TLC を行い, オートラジオグラム (ARG) を作 製した後, 削り取り法により主要代謝物の定量を 行った (Fig. 3).

\section{0. 代謝物の単離・精製}

非標識ナブメトンを投与後のラットプール尿を 䣷酸緩衝液で pH 5 に調整後, すでに述べた方法 に準じて酵素水解した. 濃塩酸で $\mathrm{pH}$ を 2 亿 調整後, 2 倍容の酢酸エチルで 2 回抽出した. 溶 媒を乾固した後, 残渣を HPLCに注入し, 尿中 代謝物の定量のところで述べたように，12個のフ ラクションに分画した. 各分画は, 以下に述べる 方法により,さらに分離・精製し代謝物を単離し た.なお, TLC は合成標品および予備実験で得 た放射性代謝物を対照として同時に展開した.

\section{代謝物 M-VI}

Fig. 2 に示した HPLC 溶出 F 1 分画を, シリ カゲルプレートに塗布し, 溶媒系(1)で展開後, 相 当する部分を溶出し, さらにシリカゲルカラム, 溶媒系(15)で精製し, 約 $60 \mathrm{mg}$ の代謝物を得た.

\section{代謝物 M-VII，M-VIII， M-IX}

F 2 分画をシリカゲルプレートに塗布し, 溶媒 系(1)で展開後, それぞれ相当する部分を溶出し た. M-VII は,さらに溶媒系(9)で展開後, HPLC で精製し約 $9 \mathrm{mg}$ 単離した. M-VIII の分画は, 溶媒系(6)で TLC を行った後, HPLC を行い約 $19 \mathrm{mg}$ を得た. M-IX の分画は, 溶媒系(7)で展開 後, RP-8 プレートを用いて溶媒系(14)でさらに 展 開した。約 $15 \mathrm{mg}$ の代謝物を得た.

\section{代謝物M-X, M-XI，M-XII}

F 3 の分画をシリカゲルプレート, 溶媒系(2)で 展開後, 相当する部分をそれぞれかきとり溶出し た. 次に, 各分画をシリカゲルプレート, 溶媒系 (15)で展開後，HPLC で精製し，それぞれ 10，1 および $50 \mathrm{mg}$ 単離した.

\section{代謝物 M-XIII}

F 5 分画をシリカゲル充填カラムに入れ, 溶媒 系(8)で展開し, 長波長 UV ランプ照射下䖝光分 画を分取した. 次に, 以下に示す 3 種類の系で TLC を行い, 最後にシリカゲルカラムを通して 精製し, 約 $45 \mathrm{mg}$ の代謝物を得た. $1: \mathrm{RP}-8$ プ レート, 溶媒系(13)，2：シリカゲルプレート, 溶 

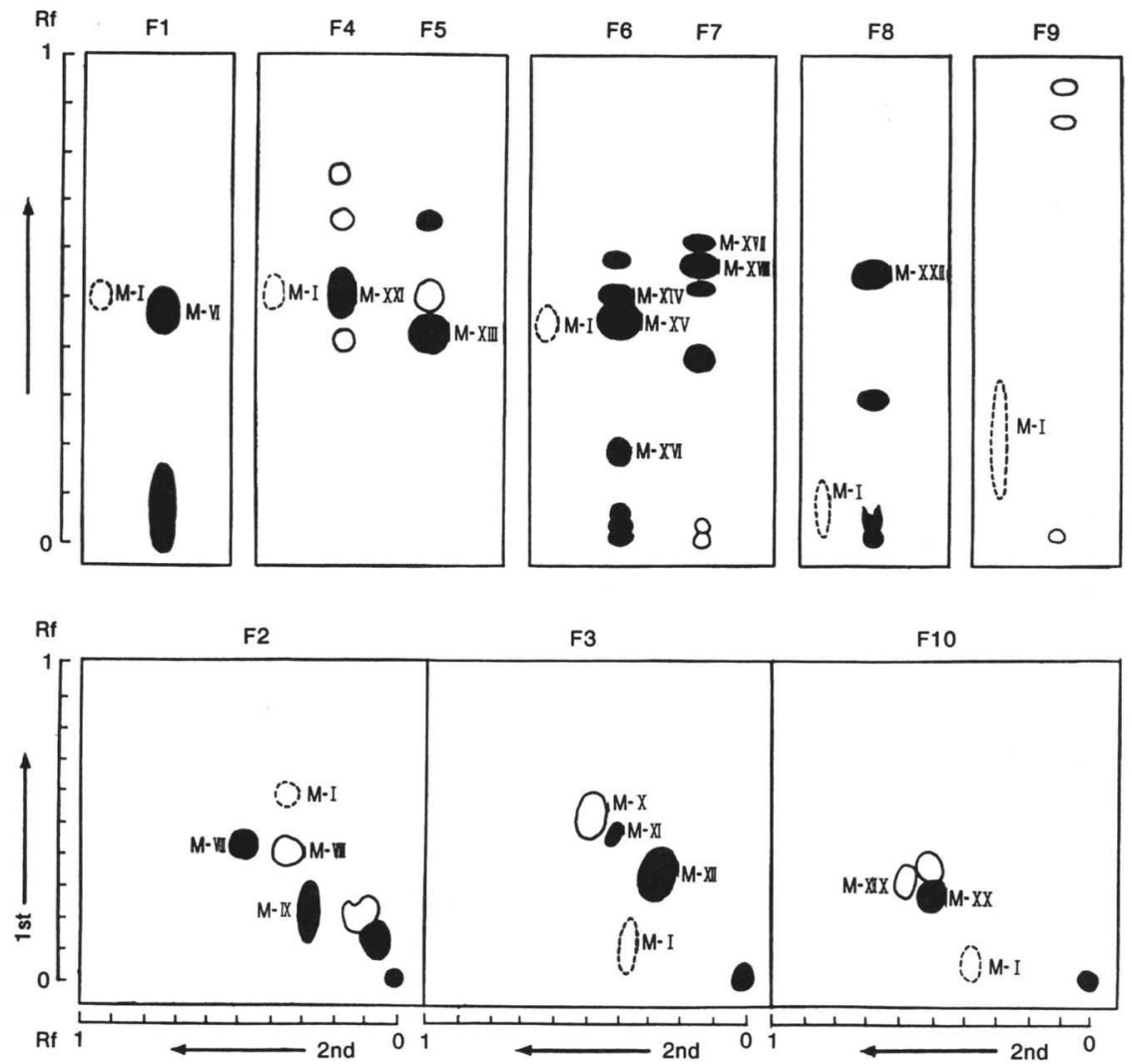

Fig. 3. Autoradiograms showing TLC separation of metabolites fractionated by HPLC after enzyme hydrolysis of rat urine.

Solvent system : Fl, system (1) ; F2, system (1), lst, system (7), 2 nd ; F3, system (15), 1st, system (2), 2 nd ; F4, F5, system (13) ; F6, F7, system (2); F8, system (10); F9, system (15) ; F10, system (10), 1st, system (2), 2 nd.

TLC plate: silica gel plates were used except that RP-8 plates were used for F4 and F5.

媒系(8), 3 : シリカゲルプレート, 溶媒系(3).

\section{代謝物 M-XIV，M-XV，M-XVI}

F 6 分画をシリカゲルプレート, 溶媒系(2)で展 開後, 相当する部分を溶出した. 次に, M-XIV と M-XV 分画をシリカゲルプレート, 溶媒系(5) でさらに展開後, HPLC で精製し, それぞれ6, $24 \mathrm{mg}$ を得た. M-XVI 分画はシリカゲルプレー ト, 溶媒系(9)で TLC を行い, HPLC で精製し て約 $8 \mathrm{mg}$ の代謝物を単離した.

\section{代謝物 M-XVII，M-XVIII}

F 7 分画をシリカゲルプレート, 溶媒系(2)で展 開後, M-XVII と M-XVIII が含まれる部分を 溶出した. 次に, 溶媒系(4)で再度展開し, 相当す る部分をかきとり HPLC で精製した。 それぞれ
$26,2.4 \mathrm{mg}$ 単離した.

\section{代謝物 M-XIX, M-XX}

F 10分画をシリカゲルプレート，溶媒系(10)で展 開後, 相当する部分を溶出した. 次に, 溶媒系(2) で展開後, HPLC で精製し, 代謝物 M-XIX, $\mathrm{M}-\mathrm{XX}$ をそれぞれ $.4,22 \mathrm{mg}$ 単離した。

\section{代謝物 M-XXI}

F 4 分画の一部をメタノールで 3 回再結晶し, 約 $100 \mathrm{mg}$ 単離した.

\section{代謝物 M-XXII}

F 8 分画をシリカゲルプレート, 溶媒系(10)で展 開後, さらに RP-8 プレート, 溶媒系 (11) で展 開 し, 相当する部分を精製し, 約 $60 \mathrm{mg}$ の代謝物 を得た。 
Table I. Spectroscopic analysis of urinary metabolites of nabumetone in rats.

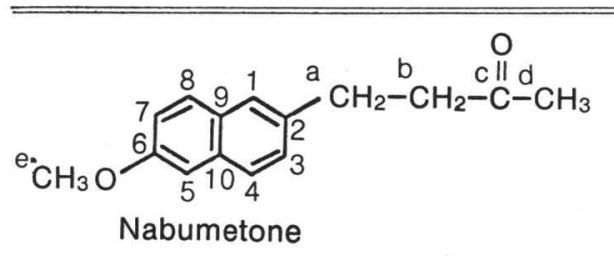

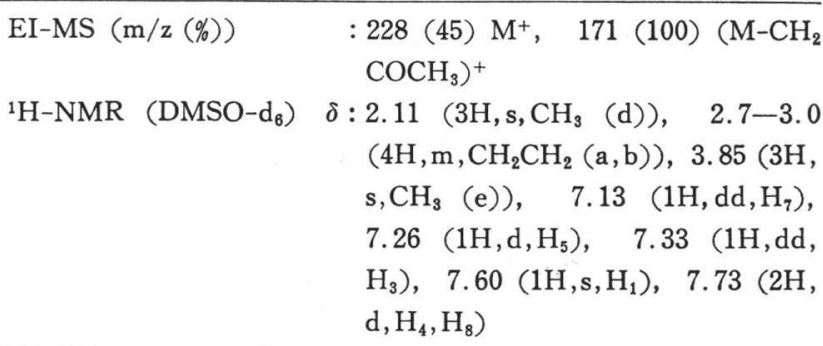<smiles>OC[C@H](O)c1ccc2cc(O)ccc2c1</smiles>

$M-V I$

EI-MS $(\mathrm{m} / \mathrm{z}(\%))$

: $204(30) \mathrm{M}^{+}, \quad 173(100)\left(\mathrm{M}-\mathrm{CH}_{2}\right.$ $\mathrm{OH})^{+}$

acetyl derivative $300(7) \mathrm{M}^{+}$

${ }^{1} \mathrm{H}-\mathrm{NMR}\left(\mathrm{DMSO}-\mathrm{d}_{6}\right) \quad \delta: 3.51\left(2 \mathrm{H}, \mathrm{d}, \mathrm{CH}_{2}(\mathrm{~b})\right), 4.65(1 \mathrm{H}$, $\mathrm{t}, \mathrm{CH}(\mathrm{a})), 4.70,5.22(1 \mathrm{H} \times 2$, brs, $\mathrm{OH} \times 2), \quad 7.06\left(1 \mathrm{H}, \mathrm{dd}, \mathrm{H}_{7}\right), \quad 7.10$ $\left(1 \mathrm{H}, \mathrm{d}, \mathrm{H}_{5}\right), \quad 7.38\left(1 \mathrm{H}, \mathrm{dd}, \mathrm{H}_{3}\right)$, $7.62\left(1 \mathrm{H}, \mathrm{d}, \mathrm{H}_{8}\right), 7.70\left(1 \mathrm{H}, \mathrm{s}, \mathrm{H}_{1}\right)$, $7.72\left(1 \mathrm{H}, \mathrm{d}, \mathrm{H}_{4}\right), \quad 9.50(1 \mathrm{H}$, brs, $\mathrm{OH})$

${ }^{13} \mathrm{C}-\mathrm{NMR}\left(\mathrm{DMSO}-\mathrm{d}_{6}\right) \quad \delta: 67.3\left(\mathrm{t}, \mathrm{CH}_{2},(\mathrm{~b})\right), \quad 73.9(\mathrm{~d}, \mathrm{CH}$ (a)), 108.4, 118.4, 124.5, 125.1, $125.4,129.1\left(\mathrm{~d}, \mathrm{C}_{1}, \mathrm{C}_{3}, \mathrm{C}_{4}, \mathrm{C}_{5}, \mathrm{C}_{7}\right.$, $\left.\mathrm{C}_{8}\right), 127.3,133.7,137.5,154.8$ $\left(\mathrm{s}, \mathrm{C}_{2}, \mathrm{C}_{6}, \mathrm{C}_{9}, \mathrm{C}_{10}\right)$

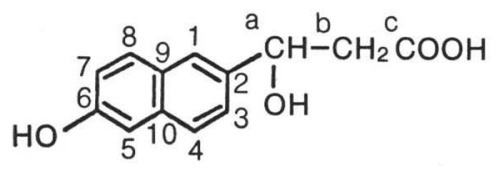

$M-V I I$
EI-MS $(\mathrm{m} / \mathbf{z}(\%))$

:232 (21) $\mathrm{M}^{+}, \quad 173$ (57) $\left(\mathrm{M}-\mathrm{CH}_{2}\right.$ $\mathrm{COOH})^{+}, \quad 170(100)(\mathrm{M}-\mathrm{OH}-$ $\mathrm{COOH})^{+}$

${ }^{1} \mathrm{H}-\mathrm{NMR}$ (DMSO- $\mathrm{d}_{6}$ ) $\delta: 2.60\left(2 \mathrm{H}, \mathrm{d}, \mathrm{CH}_{2}(\mathrm{~b})\right), 3.34(2 \mathrm{H}, \mathrm{brs}$, $\left.\mathrm{OH}, \mathrm{COOH}, \mathrm{H}_{2} \mathrm{O}\right), 5.03(1 \mathrm{H}, \mathrm{t}, \mathrm{CH}$ (a)), $7.05\left(1 \mathrm{H}, \mathrm{dd}, \mathrm{H}_{7}\right), 7.08(1 \mathrm{H}$, $\left.\mathrm{d}, \mathrm{H}_{5}\right), \quad 7.39\left(1 \mathrm{H}, \mathrm{dd}, \mathrm{H}_{3}\right), \quad 7.63$ $\left(1 \mathrm{H}, \mathrm{d}, \mathrm{H}_{8}\right), 7.70\left(1 \mathrm{H}, \mathrm{s}, \mathrm{H}_{1}\right), \quad 7.72$ $\left(1 \mathrm{H}, \mathrm{d}, \mathrm{H}_{4}\right), 9.65(1 \mathrm{H}, \mathrm{brs}, \mathrm{OH})$

${ }^{18} \mathrm{C}-\mathrm{NMR}\left(\mathrm{DMSO}-\mathrm{d}_{6}\right) \quad \delta: 44.4 \quad\left(\mathrm{t}, \mathrm{CH}_{2}\right.$ (b)), $69.6(\mathrm{~d}, \mathrm{CH}$ (a)), 108.4, 118.5, 123.9, 124.6, $125.8,129.1\left(\mathrm{~d}, \mathrm{C}_{1}, \mathrm{C}_{3}, \mathrm{C}_{4}, \mathrm{C}_{3}, \mathrm{C}_{7}\right.$, $\left.\mathrm{C}_{8}\right), 127.3,133.7,139.0,155.0$ $\left(\mathrm{s}, \mathrm{C}_{2}, \mathrm{C}_{6}, \mathrm{C}_{9}, \mathrm{C}_{10}\right), \quad 172.2(\mathrm{~s}, \mathrm{C}=0$ (c))<smiles>CC(O)C[C@H](Cc1ccc2cc(O)ccc2c1)NC(N)=O</smiles>

EI-MS $(\mathrm{m} / \mathbf{z}(\%))$

SIMS $(\mathrm{m} / \mathbf{z}(\%))$

$M-V I I I$
IR $\left(\mathrm{cm}^{-1}\right.$, nujor $)$

Elemental analysis
: $274(6) \mathrm{M}^{+}, \quad 257(11)(\mathrm{M}-\mathrm{OH})^{+}$, $172(100)$

: $275(26)(\mathrm{M}+\mathrm{H})^{+}, 215(28)(\mathrm{M}-$ $\left.\mathrm{NHCONH}_{2}\right)^{+}, 185(40)\left(\mathrm{M}-\mathrm{CONH}_{2}\right.$, $\left.-\mathrm{CHOHCH}_{3}\right)^{+}, 171(100)(\mathrm{M}-\mathrm{CO}$ $\left.\mathrm{NH}_{2},-\mathrm{CH}_{2} \mathrm{CHOHCH}_{3}\right)^{+}$ : 3100-3500 (NH), $1635(\mathrm{C}=0)$, $1560(\mathrm{NH})$

: $\mathrm{C}_{15} \mathrm{H}_{18} \mathrm{~N}_{2} \mathrm{O}_{3}$ 
${ }^{1} \mathrm{H}-\mathrm{NMR}$ (DMSO-d $\left.{ }_{6}\right) \quad \delta: 1.08\left(3 \mathrm{H}, \mathrm{d}, \mathrm{CH}_{3}\right.$ (d)), $\quad 1.5-1.9$ $\left(2 \mathrm{H}, \mathrm{m}, \mathrm{CH}_{2}\right.$ (b)), 3.5-3.8 (1H, $\mathrm{m}, \mathrm{CH}(\mathrm{c})), 4.68(1 \mathrm{H}, \mathrm{d}, \mathrm{OH}), 4.85$ $(1 \mathrm{H}, \mathrm{m}, \mathrm{CH}(\mathrm{a})), 5.50\left(2 \mathrm{H}, \mathrm{s}, \mathrm{NH}_{2}\right.$ (g)), $6.49(1 \mathrm{H}, \mathrm{d}, \mathrm{NH}(\mathrm{e})), \quad 7.06$ $\left(1 \mathrm{H}, \mathrm{dd}, \mathrm{H}_{7}\right), \quad 7.08\left(1 \mathrm{H}, \mathrm{d}, \mathrm{H}_{5}\right)$, $7.31\left(1 \mathrm{H}, \mathrm{dd}, \mathrm{H}_{3}\right), \quad 7.60(1 \mathrm{H}, \mathrm{s}$, $\left.\mathrm{H}_{1}\right), 7.63\left(1 \mathrm{H}, \mathrm{d}, \mathrm{H}_{8}\right), 7.70(1 \mathrm{H}$, $\left.\mathrm{d}, \mathrm{H}_{4}\right), 9.63(1 \mathrm{H}, \mathrm{s}, \mathrm{OH})$

${ }^{13} \mathrm{C}-\mathrm{NMR}\left(\mathrm{DMSO}-\mathrm{d}_{6}\right) \quad \delta: 23.6\left(\mathrm{q}, \mathrm{CH}_{3}\right.$ (d)), $46.7\left(\mathrm{t}, \mathrm{CH}_{2}\right.$ (b)), 50.4 (d, $\mathrm{CH}$ (a)), 62.9 (d, $\mathrm{CH}$ (c)), 108.4, 118.5, 123.9, 125.3, 125.9, $128.9\left(\mathrm{~d}, \mathrm{C}_{1}, \mathrm{C}_{3}, \mathrm{C}_{4}\right.$, $\left.\mathrm{C}_{5}, \mathrm{C}_{7}, \mathrm{C}_{8}\right), 127.4,133.4,138.9$, $154.9\left(\mathrm{~s}, \mathrm{C}_{2}, \mathrm{C}_{6}, \mathrm{C}_{9}, \mathrm{C}_{10}\right), 158.5$ (s, $\mathrm{C}=0$ (f))

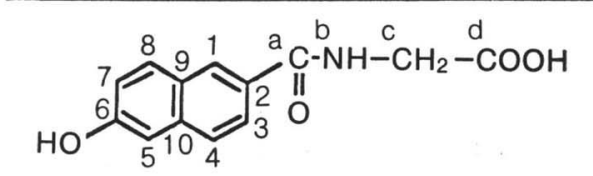

M-IX
$\operatorname{EI-MS}(\mathrm{m} / \mathrm{z}(\%))$

${ }^{1} \mathrm{H}-\mathrm{NMR}\left(\mathrm{DMSO}-\mathrm{d}_{\mathrm{B}}\right)$

$: 245(30) \mathrm{M}^{+}, 200(8)(\mathrm{M}-\mathrm{COOH})^{+}$, $171(100)\left(\mathrm{M}-\mathrm{NHCH}_{2} \mathrm{COOH}\right)^{+}$

$\delta: 3.97\left(2 \mathrm{H}, \mathrm{d}, \mathrm{CH}_{2}\right.$ (c)), $7.16(1 \mathrm{H}$, $\left.\mathrm{dd}, \mathrm{H}_{7}\right), \quad 7.18\left(1 \mathrm{H}, \mathrm{d}, \mathrm{H}_{5}\right), \quad 7.75$ $\left(1 \mathrm{H}, \mathrm{d}, \mathrm{H}_{8}\right), 7.84\left(1 \mathrm{H}, \mathrm{dd}, \mathrm{H}_{3}\right), 7.88$ $\left(1 \mathrm{H}, \mathrm{d}, \mathrm{H}_{4}\right), 8.36\left(1 \mathrm{H}, \mathrm{s}, \mathrm{H}_{1}\right), 8.85$ (1H,t, NH (b)), 10.00 (1H, brs, $\mathrm{OH}), 12.54(1 \mathrm{H}, \mathrm{brs}, \mathrm{COOH})$

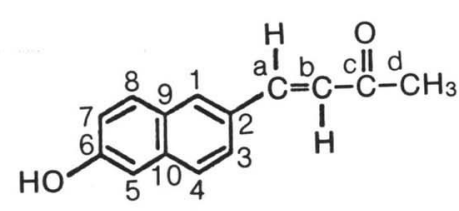

and<smiles>CC(=O)/C=C/c1ccc2cc(O)ccc2c1</smiles>

$M-X(M-X X)$

\begin{abstract}
$\operatorname{EI-MS}(\mathrm{m} / \mathrm{z}(\%))$
IR ( $\mathrm{cm}^{-1}$, nujor $)$

$212(76) \mathrm{M}^{+}, 197(100)\left(\mathrm{M}-\mathrm{CH}_{3}\right)^{+}$, $169(40)\left(\mathrm{M}-\mathrm{COCH}_{3}\right)^{+}$

: $3200(\mathrm{OH}), 1665(\mathrm{C}=\mathrm{C}), 1620(\mathrm{C}=$ O)
\end{abstract}

${ }^{1} \mathrm{H}-\mathrm{NMR} .\left(\mathrm{DMSO}-\mathrm{d}_{6}\right) \quad \delta$ : Major $2.36\left(3 \mathrm{H}, \mathrm{s}, \mathrm{CH}_{3}\right.$ (d)), 6.85 $(1 \mathrm{H}, \mathrm{d}, \mathrm{CH}$ (a) or (b)), $7.13(1 \mathrm{H}$, $\left.\mathrm{dd}, \mathrm{H}_{7}\right), \quad 7.14\left(1 \mathrm{H}, \mathrm{d}, \mathrm{H}_{5}\right), \quad 7.71$ $\left(1 \mathrm{H}, \mathrm{d}, \mathrm{H}_{8}\right), 7.72(1 \mathrm{H}, \mathrm{d}, \mathrm{CH}(\mathrm{a})$ or (b)), $7.76\left(1 \mathrm{H}, \mathrm{dd}, \mathrm{H}_{3}\right), 7.81(1 \mathrm{H}$, $\left.\mathrm{d}, \mathrm{H}_{4}\right), \quad 8.07\left(1 \mathrm{H}, \mathrm{s}, \mathrm{H}_{1}\right), \quad 10.00$ $(1 \mathrm{H}, \mathrm{s}, \mathrm{OH})$

Minor 2.20 (s), 6.28 (d, $\mathrm{CH}$ (a) or (b)), 6.95 (d, $\mathrm{CH}$ (a) or (b)), 7.64 (d), $7.71(\mathrm{~d}), 8.00$ (s)

${ }^{13} \mathrm{C}-\mathrm{NMR}\left(\mathrm{DMSO}-\mathrm{d}_{6}\right) \quad \delta:$ Major $27.3\left(\mathrm{q}, \mathrm{CH}_{3}\right.$ (d)), 109.0, 119.3, 124.1, 125.9, 126.7, 130.2, 130.2, 143.6 (d, $\mathrm{C}_{1}, \mathrm{C}_{3}, \mathrm{C}_{4}, \mathrm{C}_{5}, \mathrm{C}_{7}$, $\left.\mathrm{C}_{8}, \mathrm{C}(\mathrm{a}), \mathrm{C}(\mathrm{b})\right), 127.4,128.8$, 135.7, $157.0 \quad\left(\mathrm{~s}, \mathrm{C}_{2}, \mathrm{C}_{6}, \mathrm{C}_{9}, \mathrm{C}_{10}\right)$, $197.8(\mathrm{~s}, \mathrm{C}=\mathrm{O}(\mathrm{c}))$

Minor 30.9 (q, $\mathrm{CH}_{3}$ (d)), 108.6, $119.1,125.6,127.1,127.8,129.9$, $130.1,139.8\left(\mathrm{~d}, \mathrm{C}_{1}, \mathrm{C}_{3}, \mathrm{C}_{4}, \mathrm{C}_{5}, \mathrm{C}_{7}\right.$, $\mathrm{C}_{8}, \mathrm{C}$ (a), C (b)), 127.0, 129.5, 134.8, $156.6\left(\mathrm{~s}, \mathrm{C}_{2}, \mathrm{C}_{6}, \mathrm{C}_{9}, \mathrm{C}_{10}\right)$, $200.0(\mathrm{~s}, \mathrm{C}=\mathrm{O}(\mathrm{c}))$ 


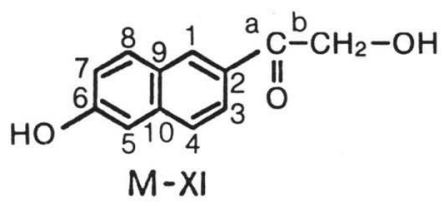

$\operatorname{EI}-\mathrm{MS}(\mathrm{m} / \mathrm{z}(\%))$

${ }^{1} \mathrm{H}-\mathrm{NMR}\left(\mathrm{DMSO}-\mathrm{d}_{6}\right) \quad \delta: 4.87\left(2 \mathrm{H}, \mathrm{d}, \mathrm{CH}_{2}(\mathrm{~b})\right), \quad 5.03(1 \mathrm{H}$, $\mathrm{t}, \mathrm{OH}), \quad 7.17\left(1 \mathrm{H}, \mathrm{dd}, \mathrm{H}_{7}\right), \quad 7.19$ $\left(1 \mathrm{H}, \mathrm{d}, \mathrm{H}_{5}\right), 7.76\left(1 \mathrm{H}, \mathrm{d}, \mathrm{H}_{8}\right), 7.84$ $\left(1 \mathrm{H}, \mathrm{dd}, \mathrm{H}_{3}\right), \quad 7.95\left(1 \mathrm{H}, \mathrm{d}, \mathrm{H}_{4}\right)$, $8.48\left(1 \mathrm{H}, \mathrm{s}, \mathrm{H}_{1}\right), 10.20(1 \mathrm{H}, \mathrm{brs}$, $\mathrm{OH})$<smiles>CC(O)C(O)C(=O)c1ccc2cc(O)ccc2c1</smiles><smiles>CC(O)C(O)C(=O)c1ccc2cc(O)ccc2c1</smiles>

$M-X \|$
EI-MS $(\mathrm{m} / \mathbf{z}(\%))$

${ }^{1} \mathrm{H}-\mathrm{NMR} \quad\left(\mathrm{DMSO}-\mathrm{d}_{6}\right) \quad \delta: 1.15\left(3 \mathrm{H}, \mathrm{d}, \mathrm{CH}_{3}(\mathrm{~d})\right), \quad 3.9-4.1$ $(1 \mathrm{H}, \mathrm{m}, \mathrm{CH}(\mathrm{c})), \quad 4.56(1 \mathrm{H}, \mathrm{d}$, $\mathrm{OH}), 4.83(1 \mathrm{H}, \mathrm{d}, \mathrm{OH}), 4.93(1 \mathrm{H}$, q, $\mathrm{CH}(\mathrm{b})), 7.17\left(1 \mathrm{H}, \mathrm{dd}, \mathrm{H}_{7}\right), 7.19$ $\left(1 \mathrm{H}, \mathrm{d}, \mathrm{H}_{5}\right), 7.75\left(1 \mathrm{H}, \mathrm{d}, \mathrm{H}_{8}\right), 7.88$ $\left(1 \mathrm{H}, \mathrm{dd}, \mathrm{H}_{3}\right), 7.96\left(1 \mathrm{H}, \mathrm{d}, \mathrm{H}_{4}\right), 8.56$ $\left(1 \mathrm{H}, \mathrm{d}, \mathrm{H}_{1}\right), 10.19(1 \mathrm{H}, \mathrm{s}, \mathrm{OH})$

${ }^{13} \mathrm{C}-\mathrm{NMR}$ (DMSO-d (D) $^{2} \quad \delta: 23.9$ (q, $\mathrm{CH}_{3}$ (d)), 68.3 (d, $\mathrm{CH}(\mathrm{b})$ or (c)), $77.2(\mathrm{~d}, \mathrm{CH}(\mathrm{b})$ or (c)), 108.7, 120.0, 124.3, 125.9, 130.6, $131.2\left(\mathrm{~d}, \mathrm{C}_{1}, \mathrm{C}_{3}, \mathrm{C}_{4}, \mathrm{C}_{5}, \mathrm{C}_{7}, \mathrm{C}_{8}\right)$, $126.0,129.1,137.2,159.1\left(\mathrm{~s}, \mathrm{C}_{2}\right.$, $\left.\mathrm{C}_{6}, \mathrm{C}_{9}, \mathrm{C}_{10}\right), 200.0(\mathrm{~s}, \mathrm{C}=\mathrm{O})$<smiles>O=C(O)c1ccc2cc(O)ccc2c1</smiles>

$M-X \mid I$
EI-MS $(\mathrm{m} / \mathrm{z}(\%))$

IR ( $\mathrm{cm}^{-1}$, nujor)

${ }^{1} \mathrm{H}-\mathrm{NMR}$ (DMSO-d $\left.\mathrm{d}_{8}\right) \quad \delta: 7.19\left(1 \mathrm{H}, \mathrm{dd}, \mathrm{H}_{7}\right), 7.22\left(1 \mathrm{H}, \mathrm{d}, \mathrm{H}_{5}\right)$, $7.77\left(1 \mathrm{H}, \mathrm{d}, \mathrm{H}_{8}\right), \quad 7.90(1 \mathrm{H}, \mathrm{dd}$, $\left.\mathrm{H}_{3}\right), 7.98\left(1 \mathrm{H}, \mathrm{d}, \mathrm{H}_{4}\right), 8.50(1 \mathrm{H}, \mathrm{d}$, $\left.\mathrm{H}_{1}\right), 11.5(2 \mathrm{H}, \mathrm{brs}, \mathrm{COOH}, \mathrm{OH})$ ${ }^{18} \mathrm{C}-\mathrm{NMR}\left(\mathrm{DMSO}-\mathrm{d}_{6}\right.$ ) $\delta: 108.6,119.4,125.4,126.1,130.5$, $131.0\left(\mathrm{~d}, \mathrm{C}_{1}, \mathrm{C}_{3}, \mathrm{C}_{4}, \mathrm{C}_{5}, \mathrm{C}_{7}, \mathrm{C}_{8}\right)$, $124.8,126.6,136.9,157.4\left(\mathrm{~s}, \mathrm{C}_{2}\right.$, $\left.\mathrm{C}_{6}, \mathrm{C}_{9}, \mathrm{C}_{10}\right), 167.6(\mathrm{~s}, \mathrm{C}=\mathrm{O}(\mathrm{a}))$<smiles>CC(O)CC(=O)c1ccc2cc(O)ccc2c1</smiles>

$M-X I V$
$\operatorname{EI}-\mathrm{MS}(\mathrm{m} / \mathrm{z}(\%))$

${ }^{1} \mathrm{H}-\mathrm{NMR}\left(\mathrm{DMSO}-\mathrm{d}_{\mathrm{B}}\right) \quad \delta: 1.17\left(3 \mathrm{H}, \mathrm{d}, \mathrm{CH}_{3}(\mathrm{~d})\right), \quad 3.01,3.24$ $\left(2 \mathrm{H}, \mathrm{d}\right.$ of $\left.\mathrm{ABq}, \mathrm{CH}_{2}(\mathrm{~b})\right), 4.1-4.3$ $(1 \mathrm{H}, \mathrm{m}, \mathrm{CH}(\mathrm{c})), 4.65(1 \mathrm{H}, \mathrm{d}, \mathrm{OH})$, $7.16\left(1 \mathrm{H}, \mathrm{dd}, \mathrm{H}_{7}\right), 7.19\left(1 \mathrm{H}, \mathrm{d}, \mathrm{H}_{5}\right)$, $7.74\left(1 \mathrm{H}, \mathrm{d}, \mathrm{H}_{8}\right), 7.87\left(1 \mathrm{H}, \mathrm{dd}, \mathrm{H}_{3}\right)$, $7.98\left(1 \mathrm{H}, \mathrm{d}, \mathrm{H}_{4}\right), 8.53\left(1 \mathrm{H}, \mathrm{s}, \mathrm{H}_{1}\right)$, $10.16(1 \mathrm{H}, \mathrm{s}, \mathrm{OH})$ 


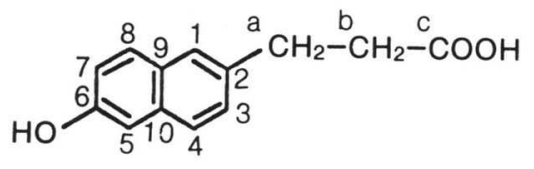

$M-X V$
$\operatorname{EI-MS}(\mathrm{m} / \mathrm{z}(\%))$

${ }^{1} \mathrm{H}-\mathrm{NMR}\left(\mathrm{DMSO}-\mathrm{d}_{6}\right) \quad \delta: 2.59\left(2 \mathrm{H}, \mathrm{t}, \mathrm{CH}_{2}\right.$ (a) or (b)), 2.92 $\left(2 \mathrm{H}, \mathrm{t}, \mathrm{CH}_{2}\right.$ (a) or (b)), $7.04(1 \mathrm{H}$ , dd, $\left.\mathrm{H}_{7}\right), \quad 7.07\left(1 \mathrm{H}, \mathrm{d}, \mathrm{H}_{5}\right), \quad 7.28$ $\left(1 \mathrm{H}, \mathrm{dd}, \mathrm{H}_{3}\right), 7.56\left(1 \mathrm{H}, \mathrm{s}, \mathrm{H}_{1}\right), 7.59$ $\left(1 \mathrm{H}, \mathrm{d}, \mathrm{H}_{8}\right), 7.66\left(1 \mathrm{H}, \mathrm{d}, \mathrm{H}_{4}\right), 9.60$ (1H, brs, OH), 12.09 (1H, brs, CO $\mathrm{OH})$<smiles>COc1ccc2cc(C(=O)NCC(=O)O)ccc2c1</smiles>

$M-X V I$
EI-MS $(\mathrm{m} / \mathbf{z}(\%))$

IR $\left(\mathrm{cm}^{-1}\right.$, nujor $)$

${ }^{1} \mathrm{H}-\mathrm{NMR} \quad\left(\mathrm{DMSO}-\mathrm{d}_{6}\right)$
: 259 (31) $\mathrm{M}^{+}, \quad 214$ (13) (M-CO $\mathrm{OH})^{+}, \quad 185(100)\left(\mathrm{M}-\mathrm{NHCH}_{2} \mathrm{CO}\right.$ $\mathrm{OH})^{+}$

: $3280(\mathrm{NH}), \quad 2600-3100(\mathrm{COOH})$, $1710,1730(\mathrm{C}=\mathrm{O})$

$\delta: 3.91\left(3 \mathrm{H}, \mathrm{s}, \mathrm{CH}_{3}(\mathrm{e})\right), \quad 3.97(1 \mathrm{H}$, d, $\left.\mathrm{CH}_{2}(\mathrm{c})\right), 7.24\left(1 \mathrm{H}, \mathrm{d}, \mathrm{H}_{7}\right), 7.39$ $\left(1 \mathrm{H}, \mathrm{d}, \mathrm{H}_{5}\right), \quad 7.90\left(2 \mathrm{H}, \mathrm{dd}, \mathrm{d}, \mathrm{H}_{3}\right.$, $\left.\mathrm{H}_{8}\right), 7.94\left(1 \mathrm{H}, \mathrm{d}, \mathrm{H}_{4}\right), 8.41(1 \mathrm{H}$, s, $\left.\mathrm{H}_{1}\right), 8.89(1 \mathrm{H}, \mathrm{t}, \mathrm{NH}$ (b)), 12.5 $(1 \mathrm{H}, \mathrm{brs}, \mathrm{COOH})$<smiles>COC(=O)Cc1ccc2cc(O)ccc2c1</smiles>

$M-X V I I$
$\operatorname{EI}-\mathrm{MS}(\mathrm{m} / \mathbf{z}(\%))$

${ }^{1} \mathrm{H}-\mathrm{NMR}\left(\mathrm{DMSO}-\mathrm{d}_{6}\right) \quad \delta: 3.62\left(3 \mathrm{H}, \mathrm{s}, \mathrm{CH}_{3}(\mathrm{c})\right), 3.76(2 \mathrm{H}, \mathrm{s}$, $\mathrm{CH}_{2}$ (a)), $7.08\left(1 \mathrm{H}, \mathrm{dd}, \mathrm{H}_{7}\right), 7.12$ $\left(1 \mathrm{H}, \mathrm{d}, \mathrm{H}_{5}\right), 7.29\left(1 \mathrm{H}, \mathrm{dd}, \mathrm{H}_{3}\right), 7.63$ $\left(1 \mathrm{H}, \mathrm{s}, \mathrm{H}_{1}\right), 7.64\left(1 \mathrm{H}, \mathrm{d}, \mathrm{H}_{8}\right), \quad 7.71$ $\left(1 \mathrm{H}, \mathrm{d}, \mathrm{H}_{4}\right), 9.70(1 \mathrm{H}, \mathrm{s}, \mathrm{OH})$<smiles>CC(=O)c1ccc2cc(O)ccc2c1</smiles>

$M-X V I I I$
$\operatorname{EI-MS}(\mathrm{m} / \mathrm{z}(\%))$

$\operatorname{SIMS}(\mathrm{m} / \mathrm{z}(\%))$

${ }^{1} \mathrm{H}-\mathrm{NMR}\left(\mathrm{DMSO}-\mathrm{d}_{6}\right) \quad \delta: 2.64\left(3 \mathrm{H}, \mathrm{s}, \mathrm{CH}_{3}(\mathrm{~b})\right), 7.17(1 \mathrm{H}$, $\left.\mathrm{dd}, \mathrm{H}_{7}\right), 7.19\left(1 \mathrm{H}, \mathrm{d}, \mathrm{H}_{5}\right), 7.75(1 \mathrm{H}$, d, $\left.\mathrm{H}_{8}\right), 7.87\left(1 \mathrm{H}, \mathrm{dd}, \mathrm{H}_{3}\right), 7.97(1 \mathrm{H}$, $\left.\mathrm{d}, \mathrm{H}_{4}\right), 8.53\left(1 \mathrm{H}, \mathrm{d}, \mathrm{H}_{1}\right), 10.2(1 \mathrm{H}$, $\mathrm{s}, \mathrm{OH}$ )

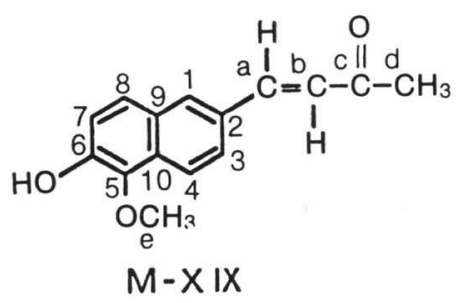

EI-MS $(\mathrm{m} / \mathrm{z}(\%))$

${ }^{1} \mathrm{H}-\mathrm{NMR}$ (DMSO- $\mathrm{d}_{6}$ )
: $242(100) \mathrm{M}^{+}, 227(99)\left(\mathrm{M}-\mathrm{CH}_{3}\right)^{+}$ $\delta: 2.36\left(3 \mathrm{H}, \mathrm{s}, \mathrm{CH}_{3}(\mathrm{~d})\right), 3.86(3 \mathrm{H}, \mathrm{s}$, $\left.\mathrm{CH}_{3}(\mathrm{e})\right), 6.86(1 \mathrm{H}, \mathrm{d}, \mathrm{CH}(\mathrm{a})$ or (b)), $7.23\left(1 \mathrm{H}, \mathrm{d}, \mathrm{H}_{7}\right), 7.60(1 \mathrm{H}$, d, $\left.\mathrm{H}_{8}\right), 7.73(1 \mathrm{H}, \mathrm{d}, \mathrm{CH}(\mathrm{a})$ or (b)), $7.80\left(1 \mathrm{H}, \mathrm{dd}, \mathrm{H}_{3}\right), \quad 7.94(1 \mathrm{H}, \mathrm{d}$, $\left.\mathrm{H}_{4}\right), 8.11\left(1 \mathrm{H}, \mathrm{d}, \mathrm{H}_{1}\right), 9.82(1 \mathrm{H}, \mathrm{s}$, $\mathrm{OH})$ 


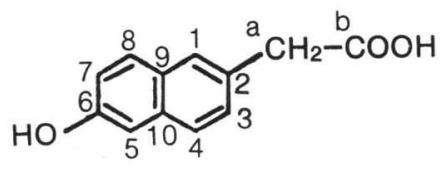

$M-X X I \quad(M-1)$
$\operatorname{EI-MS}(\mathrm{m} / \mathrm{z}(\%))$

${ }^{1} \mathrm{H}-\mathrm{NMR}$ (DMSO- $\mathrm{d}_{6}$ )
: $202(44) \mathrm{M}^{+}, 157(100)(\mathrm{M}-\mathrm{COOH})^{+}$

$\delta: 3.66\left(2 \mathrm{H}, \mathrm{s}, \mathrm{CH}_{2}\right.$ (a)), $7.07(1 \mathrm{H}$, $\left.\mathrm{dd}, \mathrm{H}_{7}\right), 7.10\left(1 \mathrm{H}, \mathrm{d}, \mathrm{H}_{5}\right), 7.29(1 \mathrm{H}$, $\left.\mathrm{dd}, \mathrm{H}_{3}\right), 7.62\left(1 \mathrm{H}, \mathrm{d}, \mathrm{H}_{1}\right), 7.63(1 \mathrm{H}$, $\left.\mathrm{d}, \mathrm{H}_{8}\right), 7.70\left(1 \mathrm{H}, \mathrm{d}, \mathrm{H}_{4}\right), 9.56(1 \mathrm{H}$, brs, OH), $12.29(1 \mathrm{H}, \mathrm{brs}, \mathrm{COOH})$<smiles>CC(=O)CCCc1ccc2cc(O)ccc2c1</smiles>

$\operatorname{EI-MS}(\mathrm{m} / \mathrm{z}(\%))$

${ }^{1} \mathrm{H}-\mathrm{NMR}\left(\mathrm{DMSO}-\mathrm{d}_{6}\right)$
: $214(25) \mathrm{M}^{+}, 157(100)\left(\mathrm{M}-\mathrm{CH}_{2} \mathrm{CO}\right.$ $\left.\mathrm{CH}_{3}\right)^{+}$

$\delta: 2.10\left(3 \mathrm{H}, \mathrm{s}, \mathrm{CH}_{3}(\mathrm{~d})\right), 2.7-3.0(4 \mathrm{H}$, $\left.\mathrm{m}, \mathrm{CH}_{2} \mathrm{CH}_{2}(\mathrm{a}, \mathrm{b})\right), \quad 7.05(1 \mathrm{H}, \mathrm{dd}$, $\left.\mathrm{H}_{7}\right), 7.08\left(1 \mathrm{H}, \mathrm{d}, \mathrm{H}_{5}\right), \quad 7.25(1 \mathrm{H}$, $\left.\mathrm{dd}, \mathrm{H}_{3}\right), 7.54\left(1 \mathrm{H}, \mathrm{s}, \mathrm{H}_{1}\right), 7.59(1 \mathrm{H}$, $\left.\mathrm{d}, \mathrm{H}_{8}\right), 7.66\left(1 \mathrm{H}, \mathrm{s}, \mathrm{H}_{4}\right), 9.60(1 \mathrm{H}$, $\mathrm{s}, \mathrm{OH}$ )

\section{実験結果}

\section{1. 代謝物の構造推定 (Table I)}

\section{M-VI}

${ }^{13} \mathrm{C}-\mathrm{NMR}$ に拉いて, 芳香族領域にナフチル基 の10個の炭素シグナル (d； 6 個, s ; 4 個), 脂肪 族領域に $\mathrm{CH}_{2}, \mathrm{CH}$ と思われるシグナルが認めら れた。 ${ }^{1} \mathrm{H}-\mathrm{NMR}$ においても，とれらを裏付ける シグナルが観測されたほか，3個の活性プロトン と思われるシグナルが認められた。 また，フェノ ール試薬との呈色反応で陽性を示したことから， この代謝物はナブメトンのメトキシ基が脱メチル 化され，側鎖炭素が 2 個減少した物質と考兄られ た. 一方, EI-MS では m/z 204 に分子イオンピ 一ク $\mathrm{M}^{+}$が, $\mathrm{m} / \mathrm{z} 173$ に $\left[\mathrm{M}-\mathrm{CH}_{2} \mathrm{OH}\right]^{+}$と思われ るフラグメントイオンピークが観測された。この 代謝物を無水䣫酸でアセチル化すると， $\mathrm{M}^{+}$が $\mathrm{m} / \mathrm{z} 330$ に変化したことは，この代謝物 1 モルに 対し 3 モルのアセチル基が導入されたことを示し て打り，先の活性プロトンの数と一致する.

以上の結果から, M-VI の化学構造を 2-hydroxy-2-(6-hydroxy-2-naphthyl)ethanol と推定し た.

\section{M-VII}

本代謝物はフェノール試薬に対して陽性を示し た. ${ }^{13} \mathrm{C}-\mathrm{NMR}$ において, $172.2 \mathrm{ppm}$ に $=\mathrm{O}$ と考えられるシグナルが観测された以外は，先の M-VI とほぼ同じ結果が得られた。一方，EI-MS でも M-VI に比べて質量数が 28 高い $\mathrm{m} / \mathrm{z} 232$ に
$\mathrm{M}^{+}$が認められた。

以上の結果から, M-VII の化学構造を 3-hydroxy-3-(6-hydroxy-2-naphthyl)propionic acid と推定した.

\section{M-VIII}

本代謝物はフェノール試薬に対して陽性を示し た. ${ }^{13} \mathrm{C}-\mathrm{NMR}$ では芳香族領域に11個の炭素シグ ナル, 脂肪族領域に $\mathrm{CH}_{3}, \mathrm{CH}_{2}$ および 2 個の $\mathrm{CH}$ と思われるシグナルが認められた. ${ }^{1} \mathrm{H}-\mathrm{NMR}$ では芳香族領域に 6 個のプロトンが，脂肪族領域 に $\mathrm{CH}_{3}, \mathrm{CH}_{2}$ および 2 個の $\mathrm{CH}$ (そのうち一方 は重水添加により multiplet から triplet に変化 した）のシグナルが認められた．その他に 5 個の 活性プロトンが観測された。これらのことより， 本代謝物は $-\mathrm{CHCH}_{2} \mathrm{CHCH}_{3}$ というナブメトン 由来の炭素鎖を有していることが推定された.

EI-MS に打いて $\mathrm{m} / \mathrm{z} 274$ に $\mathrm{M}^{+}$が, SIMS で は $\mathrm{m} / \mathrm{z} 275$ に $[\mathrm{M}+\mathrm{H}]^{+}$が観測された. 一方, 元素分析により分子式 $\mathrm{C}_{15} \mathrm{H}_{18} \mathrm{H}_{2} \mathrm{O}_{3}$ が得られ, ナ フチル基扣よび上記の推定側鎖を差し引くと, そ の差は $\mathrm{OH}$ と $\mathrm{NHCONH}_{2}$ に相当した. IR に执い て $\mathrm{NH}$ と $\mathrm{C}=\mathrm{O}$ によると思われる吸収帯が認め られ，この推定が妥当であること， SIMS に打い $\tau \mathrm{m} / \mathrm{z} 171$ に $\left[\mathrm{M}-\mathrm{CONH}_{2}-\mathrm{CH}_{2} \mathrm{CH}(\mathrm{OH}) \mathrm{CH}_{3}\right]^{+}$ と考えられるフラグメントが観測されたことか ら,本代謝物の化学構造を 4-ureido-4-(6-hydroxy-2-naphthyl)butan-2-ol と推定した.

\section{M-IX}

本代謝物はフェノール試薬に対して陽性を示し 
た. ${ }^{1} \mathrm{H}-\mathrm{NMR}$ に扔いて芳香族領域に 6 個のシグ ナルが観測されたが，そのうち2 個は，ナブメト ンおよびすでに述べた代謝物に比べて著しく低磁 場にシフトしていることから, ナフチル基に電子 吸引基の結合していることが示唆された。その他， $3.97 \mathrm{ppm}$ に $\mathrm{CH}_{2}$ 㘧よびこのプロトンとカップ リングしている 1 個の活性プロトンが認められ た. EI-MS では $\mathrm{m} / \mathrm{z} 245 に \mathrm{M}^{+}$が観測され， 窒素ルールにより本代謝物は 1 個の窒素原子を有 していることが推定された. その他， $\mathrm{m} / \mathrm{z} 200$, $\mathrm{m} / \mathrm{z} 171$ にンラグメントが観測され，それぞれ $[\mathrm{M}-\mathrm{COOH}]^{+},\left[\mathrm{M}-\mathrm{NHCH}_{2} \mathrm{COOH}\right]^{+}$とすると先 の ${ }^{1} \mathrm{H}-\mathrm{NMR}$ の結果と一致した.

以上の結果から, M-IX は (6-hydroxy-2-naphthoyl)glycine と推定した.

\section{$\mathbf{M}-\mathbf{X}, \mathbf{M}-\mathbf{X X}$}

両代謝物はいずれもフェノール試薬に対して陽 性を示し, 構造解析の結果同一物質であることが わかった。

NMR と TLC 挙動から, 本代謝物は 2 種の異 性体からなることが推定された。 ${ }^{13} \mathrm{C}-\mathrm{NMR}$ にお いて，芳香族領域にナブメトンに比べ 2 個多い 12 個の炭素シグナル (s；4 個, d; 8 個), 197.8ppm に $\mathrm{C}=\mathrm{O}$ と思われるシグナル，そして $27.3 \mathrm{ppm}$ に $\mathrm{CH}_{3}$ のシグナルが観測され，また，それぞれ のシグナルに対応する強度が $1 / 10$ のシグナルも観 測された. 一方, ${ }^{1} \mathrm{H}-\mathrm{NMR}$ では芳香族領域に 8 個（ナブメトンでは 6 個）のプロトン，2.36ppm に $\mathrm{CH}_{3}$ および $10.00 \mathrm{ppm}$ に 1 個の活性プロトン が観測され， ${ }^{13} \mathrm{C}-\mathrm{NMR}$ と同様, 各シグナルに対 応していると思われる1/10の強度を有するシグナ ルも観測された． $6.85 \mathrm{ppm}$ の 1 個のプロトンは $7.72 \mathrm{ppm}$ の 1 個のプロトンとカップリングして 特り, そのカップリング定数は $16.3 \mathrm{~Hz}$, それに 相当するマイナーなシグナルでは $12.7 \mathrm{~Hz}$ であ った. IR では $1665 \mathrm{~cm}^{-1}$ にビニル基によると思 われる吸収帯が認められた. EI-MS では $\mathrm{m} / \mathrm{z} 212$ に $\mathrm{M}^{+}, \mathrm{m} / \mathrm{z} 197$ に $\left[\mathrm{M}-\mathrm{CH}_{3}\right]^{+}$, および $\mathrm{m} / \mathrm{z} 169$ に $\left[\mathrm{M}-\mathrm{COCH}_{3}\right]^{+}$と考光られるフラグメントイオ ンピークが観測された.

以上の結果から, 本代謝物の化学構造は 4-(6hydroxy-2-naphthyl)-3-buten-2-one で, カッ プリング定数から主成分は trans 型でマイナーな
成分は cis 型と推定した.な拉, 本代謝物はTLC 展開中に互変異性化することが認められた。

\section{M-XI}

本代謝物はフェノール試薬に対して陽性を示し た. ${ }^{1} \mathrm{H}-\mathrm{NMR}$ に拈いて, M-IX と類似した芳香 族プロトンのシグナルが観測された. $4.87 \mathrm{ppm} に$ doublet の $\mathrm{CH}_{2}, 5.03 \mathrm{ppm}$ に triplet 1 個の プロトンシグナルが認められ, 重水添加により, 前者は singlet に変化し, 後者のシグナルは消失 した.このことから- $\mathrm{CH}_{2} \mathrm{OH}$ の存在が推定され た.その他 $10.20 \mathrm{ppm}$ にも，1個の活性プロト ンが認められた。一方, EI-MS に打いて, $\mathrm{m} / \mathrm{z}$ 202 に $\mathrm{M}^{+}$が, m/z 171 に $\left[\mathrm{M}-\mathrm{CH}_{2} \mathrm{OH}\right]^{+}$と思 われるフラグメントが認められた. $\mathrm{m} / \mathrm{z} 171$ は， 代謝物 M-IX でも観測されたフラグメントであ ることから, M-XI の化学構造を 6-hydroxy-2naphthyl hydroxymethyl ketone と推定した.

\section{M-XII}

本代謝物はフェノール試薬に対して陽性を示し た. ${ }^{13} \mathrm{C}-\mathrm{NMR}$ に执いて, 芳香族領域に10個の炭 素シグナル，200.0 ppm に $\mathrm{C}=\mathrm{O}$ と思われるシ グナル, さらに脂肪族領域に $\mathrm{CH}_{3}$, 特よびヘテロ 原子と結合していると思われる 2 個の $\mathrm{CH}$ シグ ナルが観測された。一方, ${ }^{1} \mathrm{H}-\mathrm{NMR}$ では, 芳香 族領域に M-IX と類似したシグナルが観測され たほか, 脂肪族領域に $\mathrm{CH}_{3}$, 互いにカップリング している 2 個の $\mathrm{CH}$ プロトンおよび 3 個の活性 プロトンのシグナルが認められ, 重水添加により 1 個の $\mathrm{CH}$ プロトンのシグナルは qualtet から doublet に変化した. これらのことから, 本代謝 物は側鎖として $-\mathrm{CO}-\mathrm{CH}(\mathrm{OH}) \mathrm{CH}(\mathrm{OH}) \mathrm{CH}_{3}$ を 有することが推定された.一方, EI-MS では $\mathrm{m} / \mathrm{z}$ 246 に $\mathrm{M}^{+}, \mathrm{M}-\mathrm{IX}$ と同様 $\mathrm{m} / \mathrm{z} 171$ にフラグメン トイオンピークが観測された.

以上の結果から, 本代謝物の化学構 造 は 2,3dihydroxy-4-(6-hydroxy-2-naphthyl) butan-4 -one と推定した.

\section{M-XIII}

本代謝物はフェノール試薬に対して陽性であっ た. ${ }^{1} \mathrm{H}-\mathrm{NMR} に$ 打いて, 芳香族領域に M-IX と 類似した 6 個のプロトンシグナルが認められた. さらに, 低磁場にも 2 個の活性プロトンのシグナ ルが認められた。 ${ }^{13} \mathrm{C}-\mathrm{NMR}$ では, 芳香族領域に 
10個のナフチル基炭素シグナルと $167.6 \mathrm{ppm}$ に $\mathrm{C}=\mathrm{O}$ と思われるシグナルが認められた。，一方， EI-MS では m/z 188 に $\mathrm{M}^{+}$が，M-IX でも見 られた $\mathrm{m} / \mathrm{z} 171$ に $[\mathrm{M}-\mathrm{OH}]^{+}$と思われるフラグ メントイオンピークが認められたことから，MXIII の化学構造を 6-hydroxy-2-naphthoic acid と推定した.

\section{M-XIV}

本代謝物はフェノール試薬に対して陽性を示し た. ${ }^{1} \mathrm{H}-\mathrm{NMR}$ において，芳香族領域に代謝物 M-IX と類似した 6 個のプロトンシグナルが認め られた。脂肪族領域では $\mathrm{CH}_{3}, \mathrm{CH}_{2}, \mathrm{CH}$ および 1 個の活性プロトンのシグナルが観測された。重 水添加により $4.1 \sim 4.3 \mathrm{ppm}$ の $\mathrm{CH}$ シグナルが 全体的に鋭く変化した，これらのことより，本代 謝物は側鎖として $-\mathrm{CH}_{2} \mathrm{CH}(\mathrm{OH}) \mathrm{CH}_{3}$ を有する ことが推定された。一方， EI-MS では $\mathrm{m} / \mathrm{z} 230$ に $\mathrm{M}^{+}$が, $\mathrm{m} / \mathrm{z} 171$ に $\left[\mathrm{M}-\mathrm{CH}_{2} \mathrm{CH}(\mathrm{OH}) \mathrm{CH}_{3}\right]^{+}$ と思われるフラグメントイオンピークが観測され た。

以上の結果, 代謝物 M-XIV の推定化学構 造 を2-hydroxy-4-(6-hydroxy-2-naphthyl)butan4-one とした.

\section{M-XV}

本代謝物はフェノール試薬に対して陽性を示し た. ${ }^{1} \mathrm{H}-\mathrm{NMR}$ において, 芳香族領域に 6 個のプ ロトンのシグナルが認められた，脂肪族プロトン としては， 2 個の $\mathrm{CH}_{2}$ シグナルが認められ， - $\mathrm{CH}_{2} \mathrm{CH}_{2}$-の存在が推定された. その他, 低磁場 に 2 個の活性プロトンのシグナルが観測された.

一方, EI-MS に拈いて m/z 216 に $\mathrm{M}^{+}$が, $\mathrm{m} / \mathrm{z}$ 157 に $\left[\mathrm{M}-\mathrm{CH}_{2} \mathrm{COOH}\right]^{+}$と思われるシグナルが 認められた。

以上の結果から, M-XV の化学構造を 3-(6hydroxy-2-naphthyl)propionic acid と推定 し た.

\section{M-XVI}

フェノール試薬に対して陰性であり, 本代謝物 は脱メチル化を受けていないことが推察された. ${ }^{1} \mathrm{H}-\mathrm{NMR}$ に打いて, $3.91 \mathrm{ppm}$ に $\mathrm{OCH}_{3}$ のシグ ナルが観測された以外は M-IX とほぼ一致した. また， EI-MS でも $\mathrm{m} / \mathrm{z} 259$ 亿 $\mathrm{M}^{+}, \mathrm{m} / \mathrm{z} 214$, $\mathrm{m} / \mathrm{z} 185$ にそれぞれ $[\mathrm{M}-\mathrm{COOH}]^{+},\left[\mathrm{M}-\mathrm{NHCH}_{2}\right.$
$\mathrm{COOH}]^{+}$と思われるフラグメントイオンが認め られ，これらはいずれも M-IX の旮れに比べ 14 $\mathrm{amu}\left(\mathrm{CH}_{2}\right)$ 大きかった.

以上の結果から, M-XVI の化学構造は (6methoxy-2-naphthoyl)glycine と推定された.

\section{M-XVII}

本物質はフェノール試薬に対して陽性を示し た. ${ }^{1} \mathrm{H}-\mathrm{NMR}$ に扔いて後述する M-XXI と類似 したスペクトルが得られたが，M-XXI で認めら れた活性プロトンのシグナルが消え，代わって $\mathrm{CH}_{3}$ シグナルが観測された.

EI-MS では m/z 216 K $\mathrm{M}^{+}$が認められ， MXXI の分子量202に比べて $14 \mathrm{amu}$ 大きいこと, $\mathrm{m} / \mathrm{z} 157$ は $\left[\mathrm{M}-\mathrm{COOCH}_{3}\right]^{+}$と考光られることか ら, 本物質の推定化学構造は 6-hydroxy-2-naphthylacetic acid methyl ester とした.

\section{M-XVIII}

本代謝物はフェノール試薬に対して陽性を示し た. ${ }^{1} \mathrm{H}-\mathrm{NMR}$ において，M-IX と類似した芳香 族プロトンシグナルが観測された. その他 $\mathrm{CH}_{3}$ と 1 個の活性プロトンのシグナルが観測された. 一方, EI-MS では m/z 186 に $\mathrm{M}^{+}$が, $\mathrm{m} / \mathrm{z} 171$ に代謝物 M-IX でも認められた $\left[\mathrm{M}-\mathrm{CH}_{3}\right]^{+}$と 考えられるフラグメントイオンピークが観測され た.

以上の結果, 代謝物 M-XVIII の化学構造を 6-hydroxy-2-naphthyl methyl ketone と推定し た.

\section{M-XIX}

本代謝物はフェノール試薬に対して陽性を示し た. ${ }^{1} \mathrm{H}-\mathrm{NMR}$ に执いて, 脂肪族プロトン領域に $\mathrm{CH}_{3}$ および互いにカップリングしたそれぞれ 1 個のプロトンに相当するシグナルが得られた（J $=16.3 \mathrm{~Hz})$. これらは $\mathrm{M}-\mathrm{X}$ で観測されたシグナ ルと類似して扮り,本代謝物は側鎖として $-\mathrm{CH}=$ $\mathrm{CHCOCH}_{3}$ を有していることが示唆された，そ の他 $3.86 \mathrm{ppm}$ にナブメトンと同様メトキシ基の $\mathrm{CH}_{3}$ シグナル，9.82 ppm に活性プロトン 1 個が 観測された. 一方, 芳香族領域では7.23，7.60， $7.94 \mathrm{ppm}$ にそれぞれオルトカップリングしたプ ロトンが， $7.80 \mathrm{ppm}$ にオルト・メタカップリン グしたプロトンが，そして $8.11 \mathrm{ppm}$ そはメタカ ップリングしたプロトンが観測された。これは， 
Table II. Quantitative determinations of metabolites excreted in the urine after oral dosing of ${ }^{14} \mathrm{C}$-nabumetone at $20 \mathrm{mg} / \mathrm{kg}$ to rats.

\begin{tabular}{|c|c|c|c|}
\hline \multirow{2}{*}{ Metabolite } & \multirow{2}{*}{ Chemical name } & \multicolumn{2}{|c|}{ Enzymic hydrolysis* } \\
\hline & & after & before \\
\hline $\mathrm{M}-\mathrm{I}$ & 6-hydroxy-2-naphthylacetic acid & 32.39 & 12.02 \\
\hline M-IV & 4-(6-hydroxy-2-naphthyl) butan-2-one & 0.78 & 0.01 \\
\hline M-VI & 2-hydroxy-2-(6-hydroxy-2-naphthyl)ethanol & 1.29 & 0.03 \\
\hline M-VII & 3-hydroxy-3-(6-hydroxy-2-naphthyl)propionic acid & 0.33 & 0.13 \\
\hline M-VIII & 4-ureido-4-(6-hydroxy-2-naphthyl)butan-2-ol & 0.08 & 0.01 \\
\hline M-IX & (6-hydroxy-2-naphthyl)glycine & 0.50 & 0.04 \\
\hline $\mathrm{M}-\mathrm{X}(\mathrm{M}-\mathrm{XX})$ & 4-(6-hydroxy-2-naphthyl)-3-buten-2-one & 0.78 & $<0.01$ \\
\hline M-XI & 6-hydroxy-2-naphthyl hydroxymethyl ketone & 1.06 & 0.04 \\
\hline M-XII & 2,3 -dihydroxy-4-(6-hydroxy-2-naphthyl) butan-4-one & 7.44 & 0.04 \\
\hline M-XIII & 6-hydroxy-2-naphthoic acid & 5.94 & 0.81 \\
\hline M-XIV & 2-hydroxy-4-(6-hydroxy-2-naphthyl)butan-4-one & 0.55 & 0.02 \\
\hline $\mathrm{M}-\mathrm{XV}$ & 3-(6-hydroxy-2-naphthyl)propionic acid & 2.89 & 0.08 \\
\hline M-XVI & (6-methoxy-2-naphthoyl)glycine & 0.32 & 0.39 \\
\hline M-XVII & 6-hydroxy-2-naphthylacetic acid methyl ester & 0.06 & $<0.01$ \\
\hline M-XVIII & 6-hydroxy-2-naphthyl methyl ketone & 0.15 & 0.01 \\
\hline $\mathrm{M}-\mathrm{XIX}$ & 4-(6-hydroxy-5-methoxy-2-naphthyl)-3-buten-2-one & 0.05 & $<0.01$ \\
\hline Total & & 54.61 & 13.63 \\
\hline
\end{tabular}

* Hydrolysis with $\beta$-glucuronidase and arylsulfatase.

(\% of dose)

代謝物 $\mathrm{M}-\mathrm{X}$ の芳香族プロトンのらち, メタカッ プリングしている 1 位あるいは 5 位のプロトンが 消失し, 代わってメトキシ基が導入されたことを 意味し，1位のプロトンが $8.11 \mathrm{ppm}$ に観測され ていることから，その位置は 5 位と考えられた. EI-MS では m/z 242 に $\mathrm{M}^{+}, \mathrm{m} / \mathrm{z} 227$ に〔M$\left.\mathrm{CH}_{3}\right]^{+}$と思われるピークが観測された。

以上の結果から，M-XIX の化学構造を 4-(6hydroxy-5-methoxy-2-naphthyl)-3-buten-2one と推定した。

\section{M-XXI}

フェノール試薬に対して陽性を示した. ${ }^{1} \mathrm{H}-\mathrm{N}$ MR において, 芳香族領域に 6 個のプロトン, $3.66 \mathrm{ppm}$ に $\mathrm{CH}_{2}$ および 2 個の活性プロトンが 観測された. EI-MS では $\mathrm{m} / \mathrm{z} 202$ に $\mathrm{M}^{+}, \mathrm{m} / \mathrm{z}$ 157 に $[\mathrm{M}-\mathrm{COOH}]^{+}$と思われるフラグメントが 認められた。.これらのデータは合成標品 M-I のそ れと一致したことから, 本代謝物を 6-hydroxy2-naphthylacetic acid と同定した.

\section{M-XXII}

本代謝物はフェノール試薬に対して陽性を示し た. ${ }^{1} \mathrm{H}-\mathrm{NMR}$ に拈いて, 芳香族領域に代謝物
M-XXI と類似した 6 個のプロトンのシグナルが 観測された・脂肪族プロトン領域には, $-\mathrm{CH}_{2} \mathrm{CH}_{2}-$ および $\mathrm{CH}_{3}$ プロトンのシグナルが観測された. これらのシグナルはナブメトンのそれとほぼ一致 した. その他 $9.60 \mathrm{ppm}$ に 1 個の活性プロトンの シグナルが認められた， EI-MS に抦いて，ナブ メトンに比べ $14 \mathrm{amu}$ 低い $\mathrm{m} / \mathrm{z} 214$ に $\mathrm{M}^{+}$が, $\mathrm{m} / \mathrm{z} 157$ に $\left[\mathrm{M}-\mathrm{CH}_{2} \mathrm{COCH}_{3}\right]^{+}$と考えられるフラ グメントイオンピークが羿められたことから, 本 代謝物はは M-IV と同一物質と推定された。

\section{2. 尿中代謝物の定量}

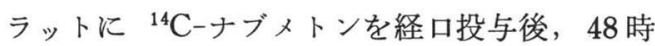
間までの尿に投与放射能の $85.4 \%$ ，粪に $11.2 \%$ が 排泄された。

4 匹の $0 \sim 48$ 時間プール尿から求めた各尿中代 謝物の割合を Table II に示した. 未変化体执よ び M-II は検出されず，M-I が投与量の $32.39 \%$ ともっとも多く, 次に, M-XII の7.44\%, M-XIII の5. $94 \%$ ，そして M-XV の $2.89 \%$ の順であり， 今回, 構造が明らかとなった代謝物を総計すると $54.6 \%$ となった）との中で非抱合体の占める割合 は約 $25 \%$ であり，残りは抱合体として排泄されて 
いることが明らかとなった。

\section{考 察}

今回, ナブメトンの尿中代謝物として17個の代 謝物を単離した。そのうち M-XXI と M-XXII は,すでに構造が明らかとなっている M-I, M-IV であり， M-X と $\mathrm{M}-\mathrm{XX}$ は同一物質, そして M-XVII は M-I のメチルェステルであった. $\mathrm{M}-\mathrm{X}$ と $\mathrm{M}-\mathrm{XX}$ は異なったフラクションから単 離していることから，これらには前駆物質があ り, 精製過程でこのような構造に変化した可能性 が考兄られる。また, M-XVII も同様に, 単離精 製過程で用いたメタノールと M-I が反応し, 生 成したと考えられる。

構造推定した代謝物のうち，M-XVI 以外はす ベて 6-hydroxy naphthyl 基を有して拉り, ナ ブメトン拉よびその代謝物のメトキシ基が体内で 脱メチル化を受けやすいことを示している。また， ナブメトンの 4 個の側鎖炭素において, 種々の酸 化・還元ならびに炭素一炭素結合の開裂などの反 応を受けていることも今回明らかになった，MXIII，M-I およびM-XV は，ナブメトンに比べ て側鎖炭素がそれぞれ 3 個, 2 個, そして 1 個少 ない酸性代謝物であり, 類似の反応が同じ側鎖を 有する raspberry ketone $\mathrm{e}^{3)}$ p zingerone $\mathrm{e}^{4)}$ で報告 されている、そこではまずケトンが二級アルコー ルささらにジオール体になり,次に炭素結合の開裂 といら反応経路が提唱されて和り，M-XV，M-I も同様な反応経路により生成していることが考光 られるが，その中間体である 1,2-ジオール体, 2, 3-ジオール体は今回単離されて括らず, さらに検 討が必要である. 一方, M-XIII に対してはジオ ール体を介した経路とは異なる経路が示唆され た.

Solheim ら5゙，ラットに特ける p-methoxy cinnamic acid の代謝経路として，まず $\beta$ 位の側 鎖炭素が水酸化された 3-hydroxy-3-(p-methoxy phenyl)propionic acid が生成し, さらに酸化さ
れて側鎖炭素が 2 個少ない p-methoxybenzoic acid と 1 個少ない p-methoxyacetophenone が 生成し, benzoic acid はさらにグリシン抱合を受 けるといら経路を報告している。

今回, 単離した代謝物の中にそれらに相当する ものが認められ，M-VII が 3-hydroxy 体で以下 M-XIII, M-XVIII，M-IX がそれらにあたる. これらのことから, M-XIII は p-methoxy cinnamic acid に相当するような中間体もしくは M$\mathrm{XV}$ から $\beta$ 位の水酸化を経て生成した可能性が考 えられる。

17 個の代謝物の中でもっとも比率の高いのが M-I であり，M-IV は1\%以下，M-II，M-III および M-V は検出されず, Haddock らの報告2) とほぼ一致した。しかし, 彼らの結果では, 酵素 水解後に求めた M-I の尿中排泄率が投与量の 43 \%を占めるのに対し，われわれの結果では $32 \%$ と 低かった. Haddock らが用いている TLC 法で 測定しても同様の結果が得られた. ただ,これら の值は 4 匹のラットのプール尿の結果であり, 個 々のラットについて定量すると, 最高值と最低值 に約15\%の差が認められ，このことは本代謝物の 生成率の個体間変動がかなりあることを示してお。 り，上記の差はこれに起因するのかもしれない。

\section{まとめ}

ラットに非ステロイド性抗炎症薬であるナブメ トンを, 経口投与後の尿から16種類の代謝物を単 離し, 構造を推定した. その結果, ナブメトンは 体内でメトキシ基の脱メチル化, 側鎖炭素上での 酸化・還元, 炭素一炭素結合の開裂ならびに抱合 など, 種々の代謝反応を受けていることが明らか となった。

主たる代謝物は投与量の $32 \%$ 占める M-I で， 次に, 7.4\%の M-XII, 5.9\%の M-XIII の順で あり，そのほとんどが抱合体として尿中に排泄さ れた、今回, 構造が明らかとなった代謝物は投与 量の約 $55 \%$ を占めた.

\section{文献}

1) Haddock, R.E., Jeffery, D.J., Mangan, F.R. and Pardon, I.S. : Penetration of nabumetone into inflammatory exudates in rats. J. Pharm. Pharmacol., 35 : 358-362 (1983).

2) Haddock, R.E., Jeffery, D.J., Lloyd, J.A. and Thawley, A.R. : Metabolism of 
nabumetone (BRL 14777) by various species including man. Xenobiotica, 14 : 327-337 (1984).

3) Sporst $\phi 1$, S. and Scheline, R.R. : The metabolism of 4-(4-hydroxy phenyl)butan2 -one(raspberry ketone) in rats, guinea pigs and rabbits. Xenobiotica, 12 : 249257 (1982).

4) Mongle, P., Scheline, R. and Solheim, E. : The metabolism of Zingerone, a Pungent Principle of Ginger. Xenobiotica, 6 : 411-423 (1976).

5) Solheim, E. and Scheline, R. : Metabolism of Alkenebenzene (Estragole) and p-Methoxy propenylbenzene (Anethole). Xenobiotica, $3: 493-510$ (1973). 